\title{
Sellar Meningioma
}

National Cancer Institute

\section{Source}

National Cancer Institute. Sellar Meningioma. NCI Thesaurus. Code C155776.

A rare meningioma that arises from the sellar region. 